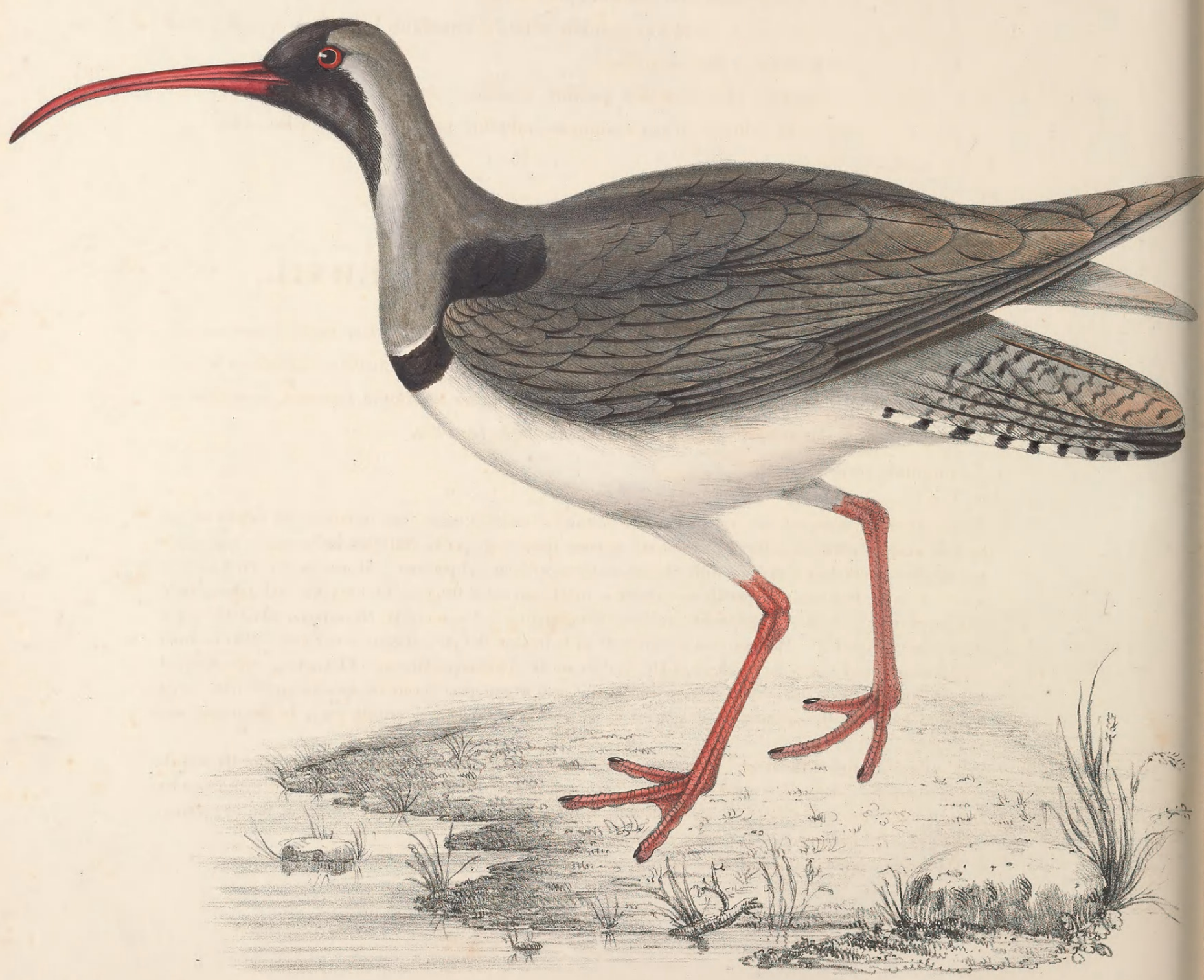

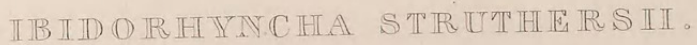




\section{Genus Imidorhyncha.}

\section{Characteres Generici.}

Rostrum gracile, elongatum, deorsùm curvatum, Ibidis Numenïque rostris simile; naribus lateralibus, longitudinalibus, membranâ per totam longitudinem clausis.

Corpus gracile, Grallatorum typicorum formam exhibens.

Alce subelongatæ, subgradatæ; remigibus secundis et tertiis æqualibus longissimis, primâ paulò breviori, cæteris gradatim decrescentibus.

Pedes mediocres, tridactyli, Hcematopodum pedibus simillimi; digitis internis liberis, externis membranâ usque ad pollicem primam connexis, omnibus marginatis ; unguibus obtusis.

Cauda mediocris, æqualis.

\section{TAB. LXXIX.}

\section{IBIDORHYNCHA STRUTHERSII.}

Ibid. corpore suprà colloque in fronte pallidè griseis; corpore subtùs albo; capitis vertice, facie guttureque nigris albo variegatis; torque pectorali subgracili, ad nucham extendente latiori, uropygioque extremo atris; rectricibus mediis fusco obscurè undulatim fasciatis, prope apicem nigro notatis, lateralium pogoniis externis albis nigro fasciatis.

Longitudo corporis, 14 unc.

Throvghout the whole of our new discoveries in the vast district which has furnished the subject of the present work, it would be difficult to point out a more interesting species than that before us, or one which has supplied ornithological science with characters more striking and peculiar. It may be observed to form a union between two groups generally considered as widely separated from each other; the body, the general form, and the legs of the Ibidorhyncha Struthersii being similar to those of the Hamatopus, while the bill is strictly that of the Ibis. We were not so fortunate as to include the present bird in our own collection from the Himalaya ; and it is to the kindness of Dr. Scouler, of the Addisonian Museum of Glasgow, — who received it from Mr. Struthers, the gentleman who collected it, and whose name forms its specific appellation, - that we are indebted for the opportunity of figuring it. Its habits and manners remain yet to be discovered and recorded.

The forehead, top of the head, and the throat, are black; a black band extends from the sides of the mantle across the chest; the neck is pale cinereous; the upper plumage ashy grey; the tail barred with irregular lines of black, the outer feathers being white with regular bars, and tipped, as are several of the succeeding, with black; the under surface is white; the beak and tarsi red.

The figure represents the bird of its natural size. 


\section{$2 \mathrm{BHL}$ Biodiversity Heritage Library}

Gould, John. 1831. "Ibidorhyncha struthersii [Tab. LXXIX]." A century of birds from the Himalaya Mountains -. https://doi.org/10.5962/p.323609.

View This Item Online: https://www.biodiversitylibrary.org/item/132967

DOI: https://doi.org/10.5962/p.323609

Permalink: https://www.biodiversitylibrary.org/partpdf/323609

\section{Holding Institution}

Smithsonian Libraries

\section{Sponsored by}

Biodiversity Heritage Library

\section{Copyright \& Reuse}

Copyright Status: Public domain. The BHL considers that this work is no longer under copyright protection.

This document was created from content at the Biodiversity Heritage Library, the world's largest open access digital library for biodiversity literature and archives. Visit BHL at https://www.biodiversitylibrary.org. 